\title{
Pengembangan Mobile Learning Untuk Penguasaan Mufrodat Siswa MTs
}

\author{
Koderi \\ Universitas Islam Negeri (UIN) Raden Intan Lampung \\ koderi@radenintan.ac.id \\ Muhammad Aridan \\ Universitas Islam Negeri (UIN) Raden Intan Lampung \\ muhamadaridan12@gmail.com \\ Ahmad Bukhari Muslim \\ Universitas Islam Negeri (UIN) Raden Intan Lampung \\ ahmadbukharimuslim@radenintan.ac.id \\ Agus Setiawan \\ Institut Agama Islam Ma'arif NU Metro Lampung \\ 4905as@gmail.com
}

\begin{abstract}
This study aims to develop Arabic language teaching media based on mobile learning and to determine the feasibility and influence of the developed media on student learning outcomes. Hannafin and Peck's development model is the model used in this study. Needs analysis, design, development and implementation are the stages in this research. This study involved material experts and media experts as validators. This study produces Arabic language teaching media products with mufrodat material based on mobile learning for Madrasah Tsanawiyah (MTs) with an offline operational system using a smartphone (Android). The feasibility of this product is classified in the very feasible category with a percentage score of $93 \%$ by material experts, $96.25 \%$ by media experts, $93 \%$ one on one trial, $86 \%$ small group trials, $92 \%$ by large group trials (field trials). Based on the results of calculations with the T-test, the value obtained $\mathrm{t} 0=62.5>\mathrm{t}$ table $=2.093$ with a difference in learning outcomes reaching 38.75. Thus the media for teaching Arabic lessons on the basis of mobile learning, the developed mufrodat material is very effective and also very suitable for use in learning Arabic.
\end{abstract}

Keywords: Mobile learning, learning media, mufrodat 


\begin{abstract}
Abstrak
Penelitian ini bertujuan untuk mengembangkan media pengajaran bahasa Arab dengan basis mobile learning dan untuk menentukan kelayakan dan pengaruh media yang dikembangkan pada hasil belajar siswa. Model pengembangan Hannafin dan Peck merupakan model yang digunakan pada penelitian ini. Analisis kebutuhan, desain, pengembangan dan implementasi merupakan tahapan dalam penelitian ini. Penelitian ini melibatkan pakar materi dan pakar media sebagai validator. Penelitian ini menghasilkan produk media pengajaran bahasa Arab materi mufrodat dengan basis mobile learning untuk Madrasah Tsanawiyah (MTs) dengan sistem operasional offline menggunakan smartphone (Android). Kelayakan produk ini diklasifikasikan dalam kategori sangat layak dengan skor persentase 93\% oleh pakar materi, 96,25\% oleh pakar media, 93\% uji coba satu banding satu, 86\% uji coba kelompok kecil, 92\% oleh uji coba kelompok besar (uji coba lapangan). Berdasarkan hasil perhitungan denganT-test, nilai diperoleh $\mathrm{t} 0=62,5>$ ttabel $=2,093$ dengan perbedaan hasil belajar mencapai 38,75. Dengan demikian media pengajaran pelajaran bahasa arabdengan basis mobile learningmateri mufrodatyang dikembangkan sangat efektif dan juga sangat layak untuk digunakan dalam pembelajaran bahasa Arab.
\end{abstract}

Kata kunci:Mobile learning,media pembelajaran, mufrodat

\title{
Pendahuluan
}

Bagi siswa pembelajaran bahasa Arab merupakan sebuahpembelajaran bahasa asing yang sulit untuk dipelajari. Kesulitan-kesulitan yang menghambat siswadalam proses pembelajaran bahasa antara lain adanya perbedaan fonologi atau bunyi, sistem penulisan, bentuk kata, susunan kalimat. ${ }^{1}$ Dengan hambatan yang ada, siswa menganggap jikamata pelajaran bahasa Arab merupakan pelajaran sulit dan rumit untuk dipelajari. ${ }^{2}$ Padahal pada dasarnya tiap bahasa mempunyaikarakteristik dan tingkat kesulitan dan kemudahannya masingmasing. Faktor internal (faktor dari dalam diri seseorang) dan faktor eksternal (faktor dari luar diri seseorang) merupakan suatu faktor yang mempengaruhi seseorang dalam belajar bahasa Arab. ${ }^{3}$ Minat, bakat, dan motivasi dari dalam diri

${ }^{1}$ Labo Efflamengo and Syamsuddin Asyrofi, 'Analisis Faktor Kesulitan Belajar Bahasa Arab Pada Siswa Tunanetra Di MAN 2 Sleman', 4.2 (2019), 43-58.

${ }^{2}$ Nisa Khoirotun and Jauharotun Ni'mah, 'Pengembnagan Bahan Ajar Maharah Al Kitabah Berbasis Pendidikan Karakter Bagi Mahasiswa Program Studi Pendidikan Bahasa Arab STAI AT - Tanwir Bojonegoro', Al-Bayan, 9 (2017), 55.

${ }^{3}$ Asep Muhammad Saepul Islam, 'Faktor Demotivasi Pembelajaran Bahasa Arab Dalam Perspektif Siswa Madrasah', Arabiyat: Jurnal Pendidikan Bahasa Arab Dan Kebahasaaraban, 2.1 (2015), 1-16 <https://doi.org/10.15408/a.v2i1.1511>. 
siswa termasuk ke dalam faktor internal atau faktor dari dalam diri siswa. Faktor eksternal misalnya guru, kurikulum, silabus, bahan ajar, model pembelajaran yaitu strategi, media dan evaluasi. ${ }^{4}$ Untuk membantu siswa dalam pembelajaran bahasa Arab diperlukan perbendeharaan mufrodat yang memadai. Hal ini diyakini dengan kesepakatan para ahli pembelajaran yang menyatakan bahwa pembelajaran mufrodat penting karena dalam pembelajaran bahasa Arab, pembelajaran mufrodat menjadi suatu syarat pembelajaran yang harus dikuasai. ${ }^{5}$ Selain itu, mufrodat juga merupakan suatu pembelajaran yang akan sangat dapat membantu siswa untuk menulis, berbicara bahkan berkomunikasi dengan bahasa Arab. Oleh karena itu, dapat dikatakan bahwa mufrodat ialah unsur bahasa yang harus dimiliki oleh pembelajarbahasa Arab. ${ }^{6}$

Sebagai pendidik alangkah baiknya untuk dapat memanfaatkan perkembangan teknologi dan ilmu pengetahuan untuk membuat media belajar yang menarik dan bertujuan untuk membantu pendidik dan siswa dalam proses kegiatan belajar mengajar. Dengan adanya media pembelajaran yang menarik bagi siswa dan membantu pendidik pada kegiatan belajar mengajar diharapkan motivasi siswa untuk belajar dan hasil belajar bahasa Arab siswa dapat meningkat. ${ }^{7}$ Pemilihan media sebagai bahan ajar tentunya sangat mempengaruhi proses pembelajaran bahasa Arab, pendidikakan sangat terbantumenyampaikan materi pada saatproses pembelajaran bahasa Arab apabila ia dapat memilih dan menggunakan media pembelajaran yang tepat.

Dalam bahasa Latin, Media memiliki arti pengantar atau perantara. ${ }^{8}$ Gerlachberpendapat bahwa, media terdiri atas manusia, bahan, peralatan, atau aktivitas yang dilalui siswa dalam mencapai pengetahuan, keterampilan, dan juga sikap. ${ }^{9}$ Dengan hal yang demikian, maka media pembelajaran dapat diartikan sebagai wahana yang bergunauntuk menyalurkanisi pembelajaran karena media merupakan sebuah alat yang dapat membantu pendidik dan juga siswa dalam suatu kegiatan pembelajaran.

${ }^{4}$ Koderi, "Penerapan Model Pembelajaran Bahasa Arab Berbasis SAVI (Somatis, Auditori, Visual, Intelektual) Dalam Meningkatkan Hasil Belajar Siswa," Jurnal Al-Bayan, 10 (2018), 75.

${ }^{5}$ roviin, 'Analisis Buku Teks Al 'Arabiyah Li Al Nasyi'in Karya Mahmud Ismail Shini, Dkk’, Al-Bayan, 10.1 (2018), file:///D:/proposal kitab amtsilati/skripsi/analis.

${ }^{6}$ Ahmad Fuad Effendy, Metodologi Pengajaran Babasa Arab (Malang: Miskyat, 2005). 126

${ }^{7}$ Gufron Amirullah and Restu Hardinata, 'Pengembangan Mobile Learning Bagi Pembelajaran', JKKP (Jurnal Kesejabteraan Keluarga Dan Pendidikan), 4.02 (2017), 97-101 $<$ https://doi.org/10.21009/jkkp.042.07>.

${ }^{8}$ Moh. Ahsanuddin Imam Asrori, Media Pembelajaran Babasa Arab (Dari Kartu Sederhana Sampai Web Penjelajah Dunia) (Malang: CV. Bintang Sejahtera, 2016). 3

${ }^{9}$ Nunu Mahnun, 'Media Pembelajaran (Kajian Terhadap Langkah-Langkah Pemilihan Media Dan Implementasinya Dalam Pembelajaran)', Jurnal An-Nida, 37 (2012), 27-35. 
Media pembelajaransangat berperan dalam proses pembelajaran bahasa Arab. ${ }^{10}$ Media pembelajaran yang digunakan dengan tepat akan sangat membantu pendidik dalam memotivasi, menarik minat siswa untuk belajar dan menambah pemahaman siswa pada pelajaran yang diberikan, sehingga akantercapai suatu tujuan pembelajaran.

Adapun beberapa manfaat media pembelajaran pada pembelajaran bahasa asing menurut Shini dan Abdullah, yaitu: Siswa akan lebih tertarik untuk belajar; Membantu siswa untuk dapat lebih fokus dalam belajarsehingga aktif dalam kegiatan belajar; Dapat membantu siswa untuk berfikir secara menyeluruh; Dapat menampilkan bermacam pengetahuan yang tidak didapat pada saat pembelajaran dilakukan tanpa mengunakan media; Dapat menigkatkan daya ingat siswa; Dapat memunculkan kesan lebih menarik dan bermakna pada kegiatan belajar bahasa. ${ }^{11}$

Pada saat pemilihan media pembelajaran pendidik juga perlu mengkaji standar media yang digunakan untuk pembelajaran. Menurut ahli media pembelajaran standar pemilihan media pembelajaran meliputi faktor kesesuaian, kualitas media serta kecakapan pendidik dalam menggunakan media tersebut. Pendidik juga perlu memperhatikan tentang; 1) keserasian tujuan pembelajaran dengan media pembelajaran, 2) ketepatgunaan media pembelajaran dalam pembelajaran, 3) relevansi antara media pembelajaran dengan kondisi siswa; 4) ketersediaan; 5) biaya terjangkau; 6) kecakapan pendidik; 7) kualitas mekanisme. ${ }^{12}$

Selain digunakan sebagai alat untuk berkomunikasi, saat ini Smartphone sangatlah multifungsi, smartphone bisa digunakan mengakses internet terutama sosial media, video call, sampai bermain game. Dalam dunia pendidikan banyak siswa yang sering menyalahgunakan smartphone selama proses kegiatan belajar mengajar (KBM) sedang berlangsung misalnya siswa lebih suka menggunakan smartphone untuk hanya sekedar bermain-main dibandingkan menuntut ilmu. ${ }^{13}$ Teknologi yang disalah gunakanakan menjadi boomerang dan juga ancaman yang mengerikan khususnya dalam bidang pendidikan. ${ }^{14}$

\footnotetext{
${ }^{10}$ Siti Mahmudah, 'Media Pembelajaran Bahasa Arab', An Nabighoh Jurnal Pendidikan dan Pembelajaran Bahasa Arab, 20.01 (2018), 129 <https://doi.org/10.32332/annabighoh.v20i01.1131>.

${ }^{11}$ Imam Asrori, Media Pembelajaran Bahasa Arab (Malang: CV. Bintang Sejahtera, 2016). 25

${ }^{12}$ Imam Asrori, Moh. Ahsanuddin, Media Pembelajaran Bahasa Arab: Dari Kartu Sederhana sampai Web Penjelajah Dunia (Malang: CV. Bintang Sejahtera, 2016), 29.

${ }^{13}$ Edi Ismanto, Melly Novalia, and Pratama Benny Herlandy, 'Pemanfaatan Smartphone Android Sebagai Media Pembelajaran Bagi Guru Sma Negeri 2 Kota Pekanbaru', Jurnal Pengabdian UntukMu NegeRI, 1.1 (2017), 42-47 < https://doi.org/10.37859/jpumri.v1i1.33>.

${ }^{14}$ Mahendra A. Nugroho Ditto R. Putra, 'Pengembangan Game Edukatif BerbasisAndroid Sebagai Media Pembelajaran Akutansi Pada Materi JurnalPenyesuaian Perusahaan Jasa', Jurnal Pendidikan Akuntansi Indonesia, 14 (2016), 25-34.
} 
Para peneliti meyakini jika smartphone dapat dikembangkan menjadi media pembelajaran dan mampu meningkatkan motivasi belajar siswa, mengingat materi pelajaran, dan keterampilan bahasa Arab. Menurut Heinich, media pembelajaran yang dapat dikatakan efektif dan juga efisien apabila media dapat menjadi, 1) sarana siswa untuk memiliki kemahiran yang dibutuhkan; 2) sarana yang memberi stimulus padasiswa untuk memperluas ilmu pengetahuan dan juga kemampuan ataupun keterampilan yang dipelajari; 3) sarana yang membantu siswa untuk mengingat materi pelajaran yang telah diberikan (retensi); dan 4) sarana yang dapat digunakan siswa untuk menerapkan kemampuandalam kondisi yang sesuai. ${ }^{15}$

Salah satu upaya untuk mengatasi problem kesulitan belajar bahasa Arab bagi siswa ialah mengembangkan mobile learning sebagai media pembelajaran bahasa Arab. ${ }^{16}$ Mobile Learning merupakan suatu model pembelajaran dimana proses belajar dilakukan dengan memanfaatkan perangkat mobile. ${ }^{17}$ Dengan pembelajaran berbasis m-learning ini, siswa dapat belajar sendiri atau belajar mandiri dimanapun dan kapanpun.Sebagaimana dikemukakan oleh Siraj yang mengutip dari Lenher, dkk bahwa: mobile learning memiliki kekuatan yaitubelajar dan mengajar kapan saja, di mana saja bahkan sambil bekerja. ${ }^{18}$ Kekuatan ini dapat menumbuhkan ketertarikan dan semangat belajar siswa sehingga hasil belajar siswa akan dapat meningkat.

Kegunaan mobile learning untuk pendidik ialah sebagai berikut: 1) memudahkan pendidik dalam menginovasi bahan ajar; 2) menambah wawasan pendidik dalam media pembelajaran; 3) memudahkan pendidik dalam mengontrol kegiatan belajar mengajar; 4) memudahkan pendidik dalam kegiatan evaluasi; 5) mengoreksi hasil evaluasi dengan cara instant. ${ }^{19}$

Penelitian Achmad Maulana pada tahun 2019 menyatakanbahwa pengembangan media pembelajaran bahasa Arab berbasis mobile learning memberikan efektivitas yang besar terhadap hasil belajar siswa. Kemudian penelitian pengembangan mobile learning bahasa Arab berbasis LSTA dengan pendekatan Addie yaitu penelitian Andri Kusuma, Firdaus Solihin, Fitri Damayanti tahun 2017.Penelitian tersebut menunjukkan bahwa pengembangan

\footnotetext{
${ }^{15}$ Koderi, 'Pembelajaran Bahasa Arab Berbasis Media IPAD', Jurnal Al-Bayan, 6 (2014), $1-18$.

${ }^{16}$ Y. Martha, Z. D., Adi, E. P., \& Soepriyanto, 'E-Book Berbasis Mobile Learning', Jurnal Kajian Teknologi Pendidikan, 1.2 (2018), 109-14.

${ }^{17}$ Koderi, 'Pengembangan Media Pembelajaran Berbasis Mobile Learning Untuk Pengajaran Bahasa Arab Di MAN Lampung', International Journal of Technology Terbaru Dan Teknik (IJRTE), 8.2S9 (2019), 107-12.

${ }^{18}$ Saedah Sinaj, 'Pembelajaran Mobile Dalam Kurikulum Masa Depan', Masalab Pendidikan, 27 (2004), 130 <http://www.myjurnal.my/public/article-view.php?id=12053>.

${ }^{19}$ Abdul Majid, "Mobile Learning”. (Makalah Pascasarjana Program Studi Pengembangan Kurikulum Universitas Pendidikan Indonesia, Bandung, 2012), 5.
} 
mobile learning sangat layak untuk digunakan sebagai media dalam pengajaran bahasa Arab. Berdasarkan paparan diatas, penelitian ini memiliki tujuan untuk dapat mengembangkan media pembelajaran bahasa Arab berbasis mobile learning materi mufrodat untuk siswa MTs kelas IX. Karena dengan mobile learning pembelajaran bahasa arab materi mufrodat dapat disajikan lebih menarik dan menyeluruh dengan materi yang ditampilkan dalam berbentuk gambar, audio, dan juga video.

Penelitian ini merupakan research and development dengan pendekatan kualitatif dan kuantitatif. Data yang berbentuk bukan angka yang didapat malalui wawancara dan observasi peniliti deskripsikan, analisa dan interpretasikan, dengan pendekatan kualitatif. Data yang berbentuk angka yang diperoleh dari hasil uji kelayakan dan efektivitas bahan ajar peneliti sajikan dengan pendekatan kuantitatif. Langkah-langkah dalam penelitian ini terdiri atas 3 tahapan yaitu, tahap analisis kebutuhan, tahan desain dan perancangan, kemudian tahap pengembangan dan implementasi sebagaimana sesuai dengan model pengembangan Hannafin and Peck (1998). ${ }^{20}$

\section{Gambar 1. Modifikasi model pengembangan Hannafin and Peck}

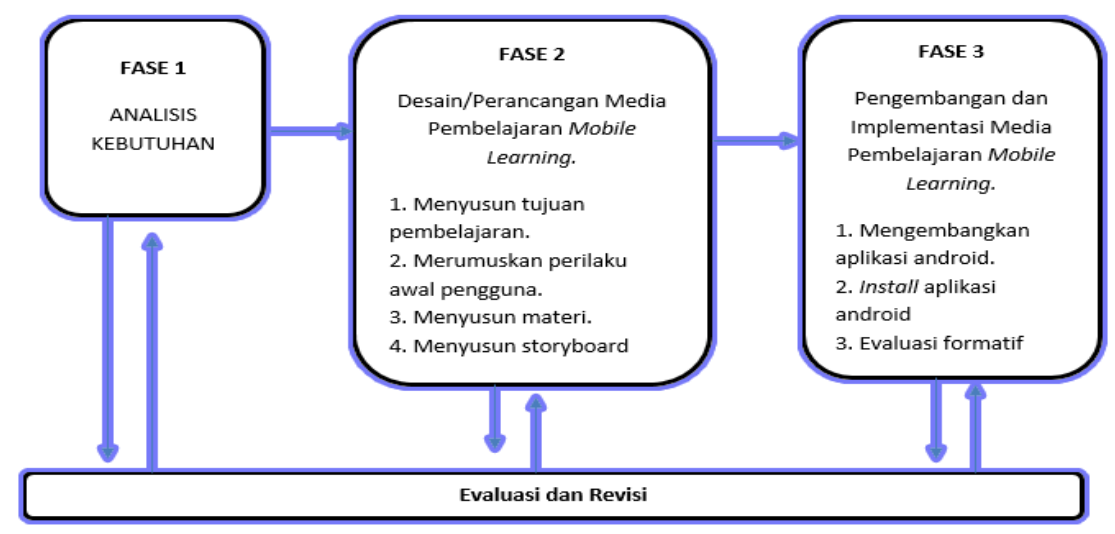

Pada fase ke-1 atau fase analisis kebutuhan, peneliti melakukan wawancara terhadap guru dan observasi ke dalam kelas. Dengan melakukan wawancara peneliti mendapatkan data sehingga dapat mensinkronkan dengan kondisi dan kebutuhan siswa. Untuk mengamati kegiatan belajar mengajar secara intesif peneliti melakukan observasi. Pada fase ke-2 atau desain/perancangan media pembelajaran mobile learning peneliti memperoleh data dengan menggunakan kusioner yang digunakan untuk menguji kelayakan produk, terdapat 3 jenis, yaitu kusioner untuk ahli materi, kusioner untuk ahli media dan kusioner untuk mengetahui respon siswa. Kemudian pada fase ke-3 atau pengembangan dan implementasi media peneliti menggunakan tes.Tes

${ }^{20}$ Sugiyono, Metode Penelitian \& Pengembangan (Research and Development), ed. oleh Sofia Yustiyanti Suryandari (Bandung: CV. Alfabeta, 2019), 39. 
berbentuk pilihan ganda dan digunakan untuk mengukur efektivitas media pembelajaran bahasa Arab materi mufrodat berbasis mobile learning yang selanjutnya dianalisa dengan uji-t.

$$
\begin{array}{ll}
\qquad \mathrm{t}=\frac{\bar{x} 1-\bar{x} 2}{\sqrt{\frac{\sum x 1^{2}+\sum x 2^{2}}{n 1+n 2+n 3} \cdot \frac{n 1+n 2}{n 1 n 2}}} \\
\mathrm{X} & =\text { Rata-rata sampel } \\
\sum_{\mathrm{n}} \mathrm{x}^{2} & =\text { Jumlah kuadrat sampel } \\
& =\text { Jumlah anggota sampel }
\end{array}
$$

\section{Hasil dan Pembahasan}

\section{Analisis Kebutuhan}

Berdasarkan wawancara terhadap tenaga pengajar bahasa Arab MTs kelas IX, didapatkan informasi bahwa mata pelajaran bahasa Arab ditempuh siswa MTs sejak dari kelas 7 hingga kelas 9 dengan bobot materi yang berbeda khususnya materi mufrodat. Pada proses pembelajaran bahasa Arab, pendidik menggunakan media pembelajaran yang terbilang klasik yaitu media pembelajaran buku cetak dan juga papan tulis. Dengan media pembelajaran tersebut, terlihat bahwa siswa kurang antusias atau aktif dalam belajar bahasa Arab.

Hasil observasi menunjukkan bahwamayoritas siswa memiliki smartphone namun tidak digunakan sebagai media pembelajaran. Saat proses belajar mengajar, siswa menggunakan buku paket yang dipinjamkan dari sekolah dengan jumlah yang terbatas dan belum menggunakan smarthhone berbasis android sebagai fasilitas media pembelajaran.

\section{Perancangan Media Pembelajaran}

Berpijak pada analisis kebutuhan, untuk meningkatkan kurangnya minat dan hasil belajar bahasa Arab siswa, maka dilakukan pengembangan media pengajaran pada pelajaran bahasa Arab dengan basis mobile learning yang sumber materinya berasal dari buku cetak yang biasa digunakan dalam pembelajaran kemudian dikemas dengan lebih menarik dan dilengkapi dengan gambar, audio, video dan juga evaluasi sebagai sarana pendukung pembelajaran.

Media pembelajaran iniberisikan materi mufrodat yang bersumber dari buku cetak siswa. Media Pembelajaran ini tersusun atas 3 bab yaitu (1) Mufrodat as-Siyaabatu wa kholqu alim, (2) MufrodatJaamalu al-Munaadziei at-thobiy'izah, (3)Mufrodatal-Huffaadæu ala al-Biy'ati.Pada semua bab memiliki kesamaan yaitu isi materi mufrodat ialah berkaitan tentang berwisata. 


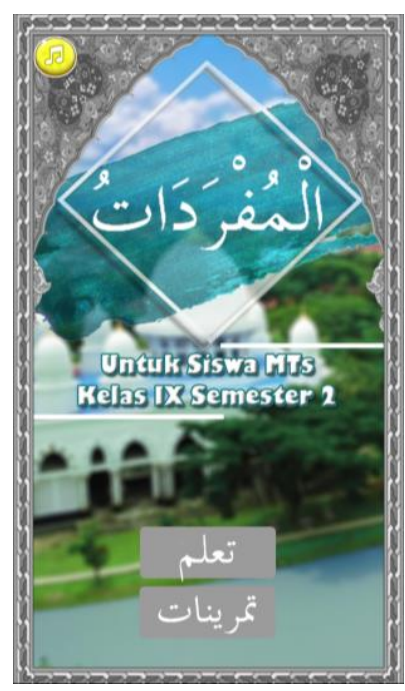

Gambar2. Tampilan awal media

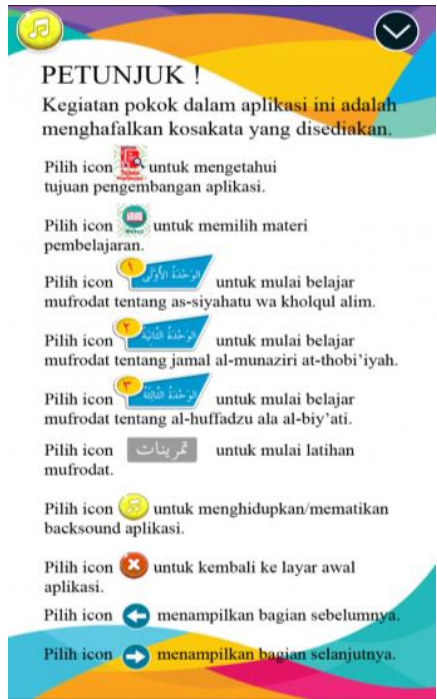

Gambar 4. Tampilan petunjuk penggunaan media

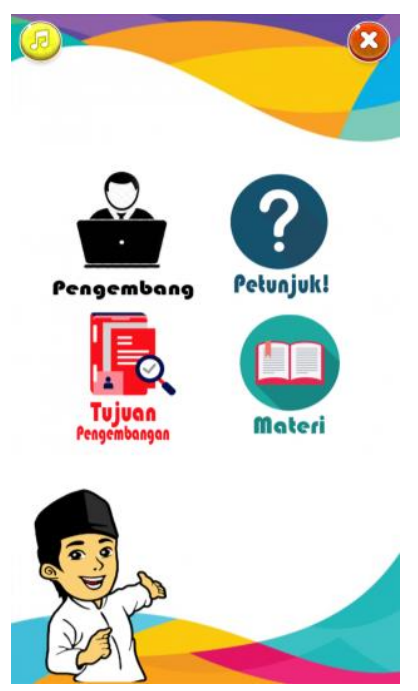

Gambar3. Tampilan menu media

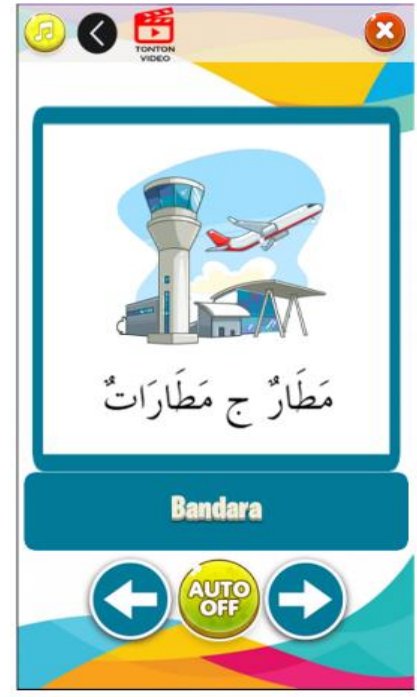

Gambar 5. Tampilan materi

Tampilan materi pada media pembelajaran ini dilengkapi dengan gambar, suara dan warna yang menarik sehingga diharapkan dapat memudahkan siswa dalam menghafal kosa kata yang diberikan. 
Selain itu media pembelajaran ini memberikan contoh-contoh penggunaan kosakata bahasa Arab yang berbentuk kalimat dalam bentuk video, sehingga siswa merasa bosan dengan tampilan yang monoton.

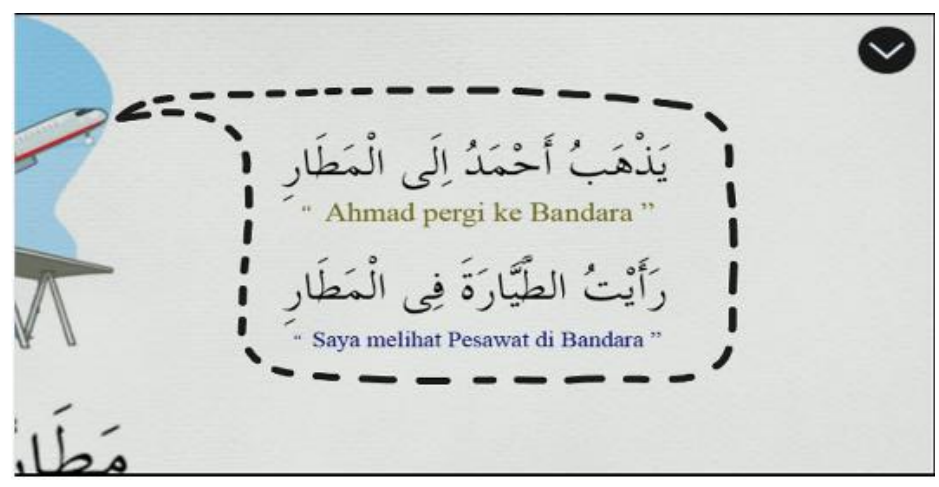

Gambar 6. Tampilan contoh kosakata dalam bentuk video

Media pembelajaran ini berisi soal-soal yang disajikan secara sederhana untuk mengevaluasi pembelajaran yang telah dilakukan. Bentuk evaluasi pada media pembelajaran ini terbagi menjadi dua, yaitu memilih jawaban yang benar dan mencocokkan gambar dengan tulisan. Evaluasi pada media pembelajaran ini juga dilengkapi waktu dan pemberian skor secara langsung yang bertujuan untuk meningkatkan minat dan kemampuan menghafal siswa terhadap materi mufrodat yang telah diberikan.

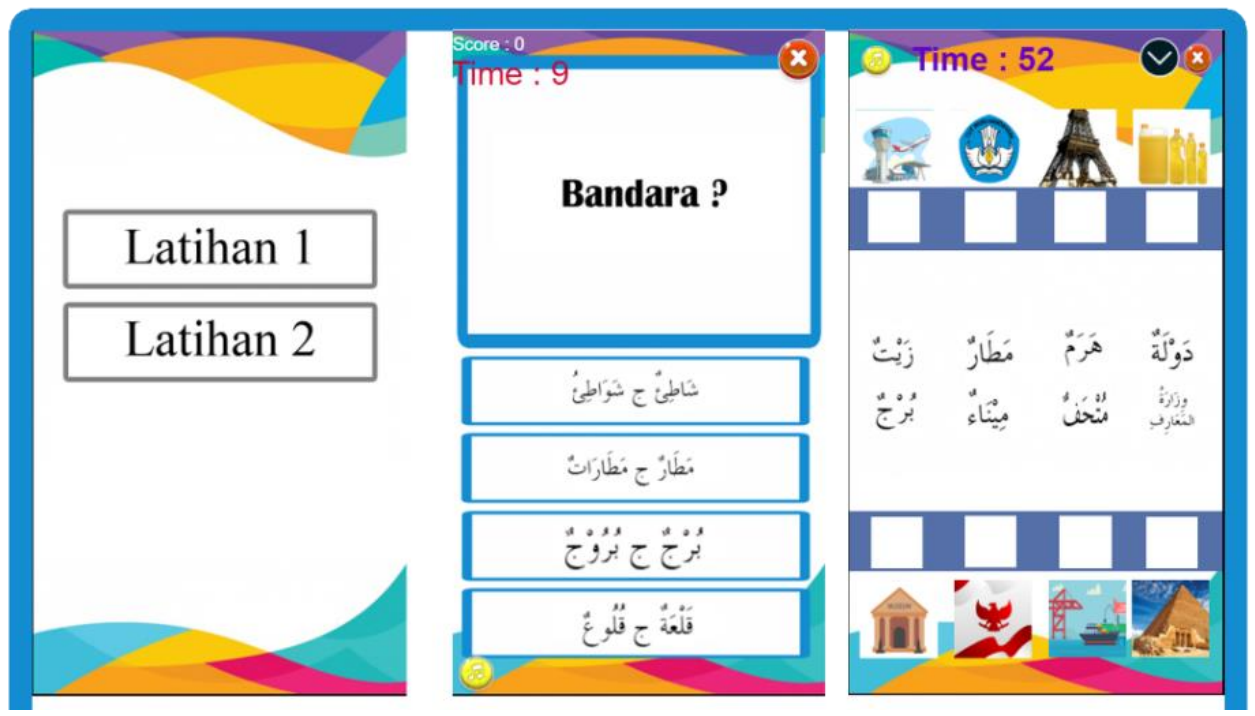

Gambar 7. Tampilan evaluasi pada Media Pembelajaran 


\section{Validitas Media Pembelajaran}

Proses validasi menyertakan 2 validator ahli materi dan 2 validator ahli media dari UIN Raden Intan Lampung. Dalam instrument validasi materi terdapat 10 butir indikator penilaian yaitu (1) Kepadanan Pelajaran; (2) Kemudahan Pelajaran; (3) Ketajaman Pelajaran; (4) Ketepatan Istilah; (5) Kearutan Gambar dan Ilustrasi; (6) Kesesuaian Materi dengan perkembangan Bahasa Arab; (7) Penyajian bersifat interaktif; (8) Menciptakan kemampuan bertanya; (9) Mendorong siswa untuk belajar Mandiri; dan (10) Evaluasi. Setiap butir soal mengandung nilai minimal 1 dan maksimal 5 .

Tabel 1. Hasil validasi materi

\begin{tabular}{|l|l|l|l|}
\hline Validator & Skor maksimal & Hasil penilaian & Persentase \\
\hline 1 & 50 & 47 & $94 \%$ \\
\hline 2 & 50 & 46 & $92 \%$ \\
\hline Jumlah & 100 & 93 & $93 \%$ \\
\hline
\end{tabular}

Dengan jumlah perolehan peresentase sebesar 93\% atau dalam kriteria sangat layak dapat ditarik kesimpulan bahwa materi pada media pengajaran pada bahasa Arab yang dikembangkan sesuai dengan kriteria. Walau demikian, terdapat beberapa masukan ataupun saran yang diberikan validator atau ahli materi sebagai bentuk perbaikan media pengajaran agar lebih baik lagi. Adapun masukannya ialah perlu ditambahkan contoh penggunaan dalam mufrodat dalam kalimat dan ditambahkan model evaluasi.

Dalam instrument validasi media terdapat 8 point indikator penilaian yaitu (1) Tampilan aplikasi sederhana; (2) Aplikasi memiliki tampilan yang menarik; (3) Aplikasi mudah dibaca dan memiiki kontras yang baik; (4) Tombol navigasi berfungsi dengan baik; (5) Audio beroperasi dengan baik; (6) Aplikasi mudah digunakan; (7) Aplikasi dapat digunakan tanpa kendala; (8) Aplikasi tidak eror. Pada tiap butir pernyataan mengandung nilai terendah 1 dan nilai tertinggi 5.

Tabel 2. Hasil validasi media

\begin{tabular}{|l|l|l|l|}
\hline Validator & Nilai maksimal & Hasil penilaian & Persentase \\
\hline 1 & 40 & 38 & $95 \%$ \\
\hline 2 & 40 & 39 & $97.5 \%$ \\
\hline Jumlah & 80 & 77 & $96.25 \%$ \\
\hline
\end{tabular}

Hasil validasi menyatakan bahwa media pengajaran pada pelajaran bahasa Arab dengan basismobile learning yang dikembangkan mencapai kriteria sangat layak dengan perolehan peresentase $96.25 \%$. Meski demikian, terdapat beberapa masukan dan saran dari validator atau ahli media sebagai bentuk optimalisasi media pengajaran agar lebih baik lagi. Adapun masukannya ialah membesarkan ukuran font pada media pembelajaran mobile learnig. 


\section{Pengembangan dan Implementasi}

Setelah melalui faseanalisis kebutuhan, fase desain, selanjutnya peneliti melakukan pengembangan dan implementasi dengan 3 (tiga) tahap uji coba, antara lain:(1) uji coba one to one learner (preseorangan) dengan jumlah responden sebanyak 3 siswa; (2) uji coba small group(kelompok kecil) dengan jumlah 9 siswa sebagai responden; dan (3) uji coba field trial (kelompok besar) dengan jumlah 20 siswasebagai responden. Uji coba ini dilakukan untuk mendapatkan respon siswa pada penggunaan media pembelajaran bahasa Arab berbasis mobile learning.

Dalam instrumen uji lapangan terdapat 10 point indikator penilaian yaitu (1) Tampilan aplikasi pembelajaran ini atraktif; (2) Media pembelajaran ini meningkatkan motivasi saya dalam belajar bahasa Arab; (3) Membuat pembelajaran bahasa Arab tidak membosankan; (4) Aplikasi ini memudahkan saya menghafal mufrodat, (5) Dengan adanya ilustrasi gambar dan video dapat mempermudah saya menghafal mufrodat, (6) Media ini menampilkan materi yang mudah untuk dipahami; (7) Aplikasi ini dapat menguji hafalan mufrodat saya dengan evaluasi yang diberikan; (8) Dalam aplikasi ini terdapat contoh kalimat yang dapat membantu saya menghafal mufrodat, (9) Media menggunakan bahasa yang sederhana dan mudah dimengeri; (10) Tulisan pada media ini mudah dibaca.

Hasil uji coba one to one learner (perorangan) pada 3 responden memperoleh skor rata-rata 2,8 atau 93\%, kemudian hasil uji coba small group (kelompok kecil) pada 9 repsonden memperoleh skor rata-rata 7,7 atau $86 \%$, hasil uji coba field trial (kelompok besar) pada 20 reponden memperoleh skor rata-rata 18,3 atau $92 \%$. Dari hasil uji coba yang telah dilaksanakan terhadap produk media pembelajaran yang dikembangkan dapat ditarik kesimpulan bahwa media pengajaran pada pelajaran bahasa Arab dengan basis mobile learning materi mufrodat sangat layak atau bisa untuk digunakan dalam pembelajaran bahasa Arab.

Untuk mengetahui efektivitas media pembelajaran yang dikembangkan, peneliti melakukan dua fase tes, yaitu pre-test dan post-test dalam pola soal pilihan ganda. Paired Sample t-test digunakan dalam menghitung skor pre-test (test sebelum menggunakan media yang dikembangkan dalam pembelajaran) dan post-test (test sesudah menggunakan media yang dikembangkan dalam pembelajaran). Untuk melakukan uji-t ini, diperlukan data prasyarat yang kemudian diuji normalitas dan homogenitasnya.

Uji normalitas dengan teknik uji tes liliefors peneliti lakukan untuk mendapati normal atau tidaknya data dalam penelitian yang di distribusikan. Dalam penelitian ini uji atau tes yang digunakan untuk mengetahui tingkat homogenitas data yang digunakan ialah uji $\mathrm{F}$ atau $F$ test. Hasil perhitungan normalitas dan homogenitas pada penelitain ini menunjukkan bahwa pre-test (test sebelum menggunakan media yang dikembangkan dalam pembelajaran) dan post- 
test (test sesudah menggunakan media yang dikembangkan dalam pembelajaran) berdistribusi normal dan homogen.

Data pada gambar 4 menunjukkan bahwa hasil belajar bahasa Arab siswa pada materi mufrodat mengalami perkembangan yang cukup signifikan, dibuktikan dengan perbedaan antara nilai terendah dan tertinggi pada nilai pretest dan post-test. Sebelum menggunakan media pengajaran mufrodat dengan basis mobile learning, hasil pre-test hanya mencapai rata-rata 52,25. Kemudian rata-rata nilai post-testatau setelah media pengajaranmufrodatdengan basis mobile learningdigunakan sebesar 87,5. Dengan demikian terdapat penigkatan sebesar 38,75 antara pre-test dan post-test.

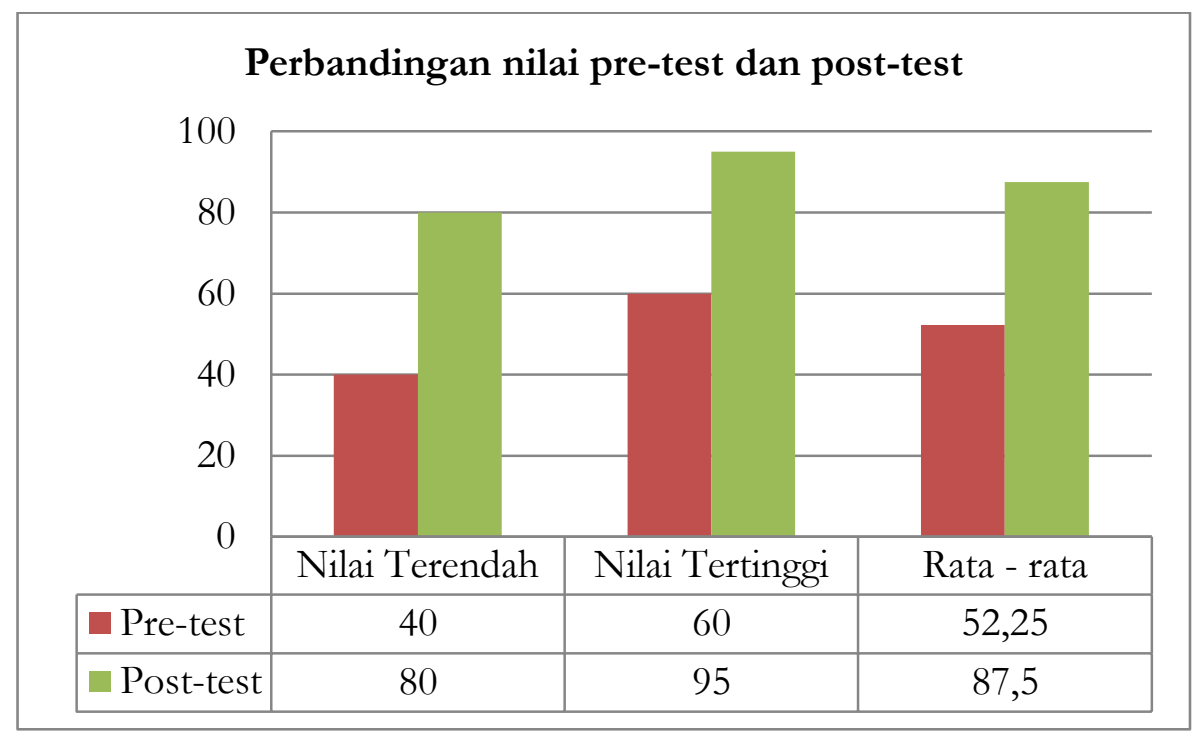

Gambar 8. Grafik perbandingan nilai pre-test dan post-test

Berlandaskan hasil dari uji-t yang telah dilakukan, didapati bahwa $\mathrm{t}_{0}=$ 62,5sedangkan $t_{\text {tabel }}=2,093$ pada tingkat signifikan $\alpha=0,05$. Hasil bandingan antara nilai $t_{0}$ dan $t_{\text {tabel }}$ adalah $t_{0}=62,5>t_{\text {tabel }}=2,093$. Dengan $H_{0}$ pada hipotesis tersebut ditolak dan $\mathrm{H}_{1}$ pada hipotesis tersebut diterima, maka dapat ditarik sebuah kesimpulan yakni media pengajaran bahasa Arab dengan basis mobile learning materi mufrodat untuk siswa kelas IX A MTs Al-Jauhar Bandar Lampung adalah efektif dalam meningkatkan hasil belajar bahasa Arab siswa.

\section{Penutup}

Media pembelajaran mufrodat berbasis mobile learning materi dinilai sangat layak untuk diterapkan dalam kegiatan belajar mengajar bahasa Arab. Disamping itu, media pembelajaran ini dinilai efektif untuk digunakan dalam proses belajar bahasa Arab materi mufrodat dengan keefektivan produk yang diperoleh dari perbandingan hasil belajar sejumlah 38,75 dengan skor hasil analisis uji- $\mathrm{T}$ t0 $=$ 
$62,5>$ ttabel $=2,093$. Meningkatnya hasil belajar siswa ditunjukkan melalui hasil pre-test dan post-test yang menyatakan bertambahnya kemampuan siswa dalam menghafal mufrodat. Ini menunjukkan bahwa media pembelajaran yang dikembangkan efektif untuk mengatasi kesulitan menghafal kosakata bagi siswa. Dibandingkan dengan penelitian sebelumnya, penelitian ini menciptakan produk media pembelajaran yang khusus pada materi mufrodat dengan dilengkapi suara, gambar, evaluasi, dan contoh-contoh yang disajikan dalam bentuk video. Hal ini membuat produk ini efektif, efisien dan juga menarik.

\section{Bibliografi}

Amirullah, Gufron, and Restu Hardinata, 'Pengembangan Mobile Learning Bagi Pembelajaran', JKKP (Jurnal Kesejabteraan Keluarga Dan Pendidikan), 4.02 (2017), 97-101 <https://doi.org/10.21009/jkkp.042.07>

Asrori, Imam, Media Pembelajaran Babasa Arab (Malang: CV. Bintang Sejahtera, 2016)

Ditto R. Putra, Mahendra A. Nugroho, 'Pengembangan Game Edukatif BerbasisAndroid Sebagai Media Pembelajaran Akutansi Pada Materi JurnalPenyesuaian Perusahaan Jasa', Jurnal Pendidikan Akuntansi Indonesia, 14 (2016), 25-34

Effendy, Ahmad Fuad, Metodologi Pengajaran Babasa Arab (Malang: Miskyat, 2005) Efflamengo, Labo, and Syamsuddin Asyrofi, 'Analisis Faktor Kesulitan Belajar Bahasa Arab Pada Siswa Tunanetra Di MAN 2 Sleman', 4.2 (2019), 43-58

Imam Asrori, Moh. Ahsanuddin, Media Pembelajaran Babasa Arab (Dari Kartu Sederbana Sampai Web Penjelajah Dunia) (Malang: CV. Bintang Sejahtera, 2016)

Islam, Asep Muhammad Saepul, 'Faktor Demotivasi Pembelajaran Bahasa Arab Dalam Perspektif Siswa Madrasah', ARABIYAT :Jurnal Pendidikan Bahasa Arab Dan Kebahasaaraban, 2.1 (2015), 1-16 $<$ https://doi.org/10.15408/a.v2i1.1511>

Ismanto, Edi, Melly Novalia, and Pratama Benny Herlandy, 'Pemanfaatan Smartphone Android Sebagai Media Pembelajaran Bagi Guru Sma Negeri 2 Kota Pekanbaru', Jurnal Pengabdian UntukMu NegeRI, 1.1 (2017), 42-47 $<$ https://doi.org/10.37859/jpumri.v1i1.33>

Khoirotun, Nisa, and Jauharotun Ni'mah, 'Pengembnagan Bahan Ajar Maharah Al - Kitabah Berbasis Pendidikan Karakter Bagi Mahasiswa Program Studi Pendidikan Bahasa Arab STAI AT - Tanwir Bojonegoro', Al-Bayan, 9 (2017), 55

Koderi, 'Pembelajaran Bahasa Arab Berbasis Media IPAD', Jurnal Al-Bayan, 6 
(2014), 1-18

, 'Penerapan Model Pembelajaran Bahasa Arab Berbasis SAVI (Somatis, Auditori, Visual, Intelektual) Dalam Meningkatkan Hasil Belajar Peserta Didik', Jurnal Al-Bayan, 10 (2018), 75-86

_ Pengajaran Bahasa Arab Di MAN Lampung', International Journal of Technology Terbaru Dan Teknik (IJRTE), 8.2S9 (2019), 107-12

Mahmudah, Siti, 'Media Pembelajaran Bahasa Arab', An Nabighob Jumal Pendidikan Dan Pembelajaran Babasa Arab, 20.01 (2018), 129 <https://doi.org/10.32332/an-nabighoh.v20i01.1131>

Mahnun, Nunu, 'Media Pembelajaran (Kajian Terhadap Langkah-Langkah Pemilihan Media Dan Implementasinya Dalam Pembelajaran)', Jurnal AnNida, 37 (2012), 27-35

Majid, Abdul, 'Mobile Learning' (Universitas Pendidikan Indonesia, 2012)

Martha, Z. D., Adi, E. P., \& Soepriyanto, Y., 'E-Book Berbasis Mobile Learning', Jurnal Kajian Teknologi Pendidikan, 1.2 (2018), 109-14

roviin, 'Analisis Buku Teks Al 'Arabiyah Li Al Nasyi'in Karya Mahmud Ismail Shini, Dkk', Al-Bayan, 10.1 (2018), file:///D:/proposal kitab amtsilati/skripsi/analis

Sinaj, Saedah, 'Pembelajaran Mobile Dalam Kurikulum Masa Depan', Masalah Pendidikan, 27 (2004), 130 <ttp://www.myjurnal.my/public/articleview.php?id=12053>

Sugiyono, Metoden Penelitian \& Pengembangan (Research and Development), ed. by Sofia Yustiyanti Suryandari (Bandung: CV. Alfabeta, 2019) 